\title{
ASAS PROPORSIONALITAS DALAM PERJANJIAN JUAL BELI SCRAP ANTARA PT. PERTAMINA REFINERY UNIT IV DENGAN VENDOR
}

\author{
Sandytias Dwi Putera \\ E-mail: puterasandy@yahoo.co.id \\ Mahasiswa Fakultas Hukum Universitas Sebelas Maret \\ Anjar Sri Ciptorukmi Nugraheni \\ E-mail: anjarsri@staff.uns.ac.id \\ Dosen Fakultas Hukum Universitas Sebelas Maret
}

\begin{abstract}
The article aims to know and analyze the basic application of proportionality in the formation phase and the implementation stage of scrap purchase agreements between PT. Pertamina RU $I V$ Cilacap and the vendors. This research belongs to the type of empirical law research that is descriptive by using a qualitative approach. The data used is primary data and secondary data. Data collection techniques using interviews and literature studies. Technical analysis of data used by authors is a qualitative analysis with interactive analysis models. The results showed that the principle of proportionality has been applied to the establishment and implementation of scrap purchase agreements between PT. Pertamina RU IV Cilacap with the vendors. At the stage of the formation consisting of the negotiation stage, and the drafting phase of the agreement has applied the principle of proportionality by using 4 principles namely the principle of equality of rights, principles of freedom, proportional distribution principle, and the win-win solution principle. The principle of proportionality has also been applied to the implementation of scrap purchase agreements using the principle of equality of rights, principles of freedom, proportional distribution principle so that PT. Pertamina RUIV Cilacap as the seller and vendor as The buyer has applied the principle of proportionality to all phases of the agreement which starts from the negotiation stage until the implementation of the agreement in achieving a fair exchange of rights and obligations for the parties.
\end{abstract}

Keywords : The principle of Proportionality; Scrap Purchase Agreement; Phase of Agreement Establishment; Phase of Implementation of the Agreement

\begin{abstract}
Abstrak
Artikel bertujuan untuk mengetahui dan menganalisis penerapan asas proporsionalitas dalam tahap pembentukan dan tahap pelaksanaan perjanjian jual beli scrap antara PT. Pertamina RU IV Cilacap dengan vendor. Penelitian ini termasuk ke dalam jenis penelitian hukum empiris yang bersifat deskriptif dengan menggunakan pendekatan kualitatif. Data yang digunakan merupakan data primer dan data sekunder. Teknik pengumpulan data menggunakan wawancara dan studi kepustakaan. Teknis analisis data yang digunakan penulis merupakan analisis kualitatif dengan model analisis interaktif. Hasil penelitian menunjukkan bahwa asas proporsionalitas telah diterapkan pada tahap pembentukan dan pelaksanaan perjanjian jual beli scrap antara PT. Pertamina RU IV Cilacap dengan vendor. Pada tahap pembentukan yang terdiri dari tahap negosiasi, dan tahap penyusunan perjanjian telah menerapkan asas proporsionalitas dengan menggunakan 4 prinsip yaitu prinsip kesetaraan hak, prinsip kebebasan, prinsip distribusi
\end{abstract}


proporsional, dan prinsip win-win solution. Asas proporsionalitas juga telah diterapkan pada tahap pelaksanaan perjanjian jual beli scrap dengan menggunakan prinsip kesetaraan hak, prinsip kebebasan, prinsip distribusi proporsional sehingga PT. Pertamina RU IV Cilacap selaku penjual dan vendor selaku pembeli telah menerapkan asas proporsionalitas pada seluruh tahapan dalam perjanjian yang dimulai dari tahap negosiasi sampai tahap pelaksanaan perjanjian dalam mencapai pertukaran hak dan kewajiban yang adil bagi para pihak.

Kata Kunci : Asas Proporsionalitas; Perjanjian Jual Beli Scrap; Tahap Pembentukan Perjanjian; Tahap Pelaksanaan Perjanjian Pendahuluan

\section{A. Pendahuluan}

Aset milik PT. Pertamina (Persero) tidak selamanya akan digunakan secara terus menerus. Terdapat masanya bahwa aset yang dimiliki tersebut memiliki penurunan kualitas sehingga perlu adanya penghapusan aset barang yang tidak digunakan (selanjutnya dapat disebut dengan scrap). Pelepasan dan penghapusan aset scrap tidak selalu berjalan dengan lancar sehingga dewasa ini permasalahan mengenai pelepasan aset scrap yang terjadi pada PT. Pertamina (Persero) Refinery Unit IV (selanjutnya dapat disebut PT. Pertamina) masih terjadi salah satunya terdapat pada perjanjian jual beli scrap.

Perjanjian Jual Beli Scrap PT. Pertamina dengan Vendor mengacu beberapa asas perjanjian termasuk asas proporsionalitas dan asas keseimbangan. Asas proporsionalitas dan asas keseimbangan memiliki hubungan antara satu sama lain dalam proses berkontrak. Namun eksistensi asas keseimbangan lebih sering dihubungkan dalam proses berkontrak daripada asas proporsionalitas. Menurut Agus Yudha Hernoko, hal ini dikarenakan terdapat beberapa perbedaan antara asas keseimbangan dan asas proporsionalitas apabila ditinjau menurut daya kerjanya. Daya kerja asas keseimbangan lebih menekankan pada aspek keseimbangan posisi dalam berkontrak sehingga tujuan asas ini supaya hasil akhir yang menempatkan kedudukan yang seimbang antara kedua belah pihak dalam menentukan hak dan kewajiban sedangkan daya kerja asas proporsionalitas lebih menekankan pada proporsionalnya pembagian hak dan kewajiban dalam keseluruhan aspek kontraktual (Agus Yudha Hernoko, 2016 : Volume 5 Nomor 3 Halaman 447-466). Proporsionalitas dalam hal ini lebih mengutamakan pembagian hak dan kewajiban dalam membuat kontrak tersebut dan seyogyanya dilakukan secara layak dan patut (fair and reasonableness) (Agus Yudha Hernoko, 2010 : 89). Maka dari itu, keterkaitan proporsionalitas dalam kebebasan berkontrak pun memiliki kaitan yang erat baik pada tahap membuat perjanjian maupun pada isi klausula perjanjian maupun pelaksanaan perjanjian yang dibuat tersebut.

Minat masyarakat akan barang scrap masih tinggi sehingga terkadang mereka mengesampingkan pentingnya proporsionalitas terhadap klausula dalam perjanjian jual beli scrap tersebut. Penerapan Asas Proporsionalitas pada perjanjian jual beli scrap antara PT. Pertamina dan vendor merupakan hal yang penting dikaji dan ditelaah guna mengakomodir kepentingan kedua belah pihak (pembeli dan penjual) secara proporsional. Hal ini dikarenakan beberapa hal yaitu, pertama, nilai nominal aset scrap yang tercantum dalam perjanjian berkisar ratusan juta sampai miliar rupiah. Kedua, aset scrap PT. Pertamina yang menjadi objek dalam perjanjian ini pun juga merupakan aset milik negara sehingga apabila ketidakproporsionalitas ini terjadi, maka negara pun ikut menanggung kerugian atas ketidakproporsionalitasan 
dari perjanjian jual beli scrap. Ketiga, terdapat klausula yang tertuang pada perjanjian sebagaimana hal tersebut merupakan aturan baku yang ditetapkan secara sepihak oleh PT. Pertamina sehingga vendor hanya dapat menyetujui atau tidak atas pencantuman atas klausula tersebut sehingga dapat terciptanya ketidakseimbangan posisi antara PT. Pertamina dengan vendor. Berdasarkan hal tersebut, pentingnya untuk penerapan proporsionalitas dalam tahap pembentukan maupun tahap pelaksanaan perjanjian jual beli scrap antara kedua belah pihak supaya pihak penjual (PT. Pertamina) dan pembeli (vendor) tidak mengalami kerugian dan terpenuhinya kepentingan kedua belah pihak secara proporsional.

Berdasarkan dari uraian tersebut, maka dalam artikel ini membahas mengenai bagaimana penerapan asas proporsionalitas dalam pembentukan dan pelaksanaan perjanjian jual beli scrap antara PT. Pertamina dengan vendor.

\section{B. Metode Penelitian}

Penelitian ini termasuk ke dalam jenis penelitian hukum empiris. Sifat penelitian yang digunakan yaitu penelitian deskriptif dengan menggunakan pendekatan kualitatif. Jenis data penelitian yang digunakan yaitu data primer (data yang berasal narasumber) dan data sekunder (data yang berasal dari bahan pustaka) (Soerjono Soekanto, 2014:50-51). Teknik pengumpulan data yang digunakan oleh penulis dalam melakukan penelitian yaitu wawancara, dan studi kepustakaan. Data pada penelitian ini bersifat kualitatif sehingga dianalisis dengan teknik analisis hukum dengan mengumpulkan, mengklasifikasikan, dan menyeleksi data yang diperoleh dari penulisan hukum lapangan, kemudian dihubungkan dengan teori-teori, asasasas, kaidah-kaidah hukum yang diperoleh melalui studi kepustakaan dengan melibatkan tiga komponen utama yaitu : reduksi data, penyajian data, dan penarikan kesimpulan (H.B. Soetopo, 2006: 113).

\section{Hasil Penelitian dan Pembahasan}

\section{Hasil Penelitian}

Tahap dalam perjanjian jual beli scrap terdiri dari 2 tahap yaitu :

a. Tahap Pembentukan Perjanjian jual beli scrap yang terdiri atas :

1) tahap negosiasi dan tahap penyusunan perjanjian. Tahap negosiasi dalam perjanjian jual beli scrap ini terdiri atas :

a) Agenda Penjelasan Rencana Kerja dan Syarat-syarat

Merupakan pertemuan untuk menjelaskan dan membahas draft Rencana Kerja dan Syarat-Syarat (RKS) dan syarat lelang dalam hal pelepasan jual beli scrap yang akan dilakukan. Pembentukan RKS terlebih dahulu dibentuk oleh PT. Pertamina namun vendor juga diberikan kesempatan untuk mengusulkan revisi Rencana Kerja dan Syarat-Syarat (RKS) apabila terdapat hal yang tidak sesuai dengan apa yang diinginkan atau dibutuhkan oleh vendor. Berdasarkan Berita Acara Aanwijzing tertanggal 23 Mei 2016 yang telah disepakati, tidak adanya revisi terkait Rencana Kerja dan Syaratsyarat (RKS) (hasil wawancara dengan bapak Ardhian Prasetyo pada hari Rabu tanggal 10 April 2019 Pukul 13.30 WIB). 
b) Pelaksanaan Lelang

Pelaksanaan lelang menggunakan Kantor Pelayanan Kekayaan Negara dan Lelang (KPKNL) pada Selasa, 24 Mei 2006 dengan berdasarkan Peraturan Menteri Keuangan Nomor: 27/PMK.06/2016 tentang Petunjuk Pelaksanaan Lelang. Barang yang dilelang oleh PT. Pertamina berupa 1 (satu) paket barang-barang bekas (Scrap ferrous/non ferrous). Peserta Lelang Scrap diikuti oleh 22 peserta dan salah satunya yaitu PT. Sokojati Bumi Serasi (yang selanjutnya disebut PT. SBS). Tujuan PT. SBS mengikuti lelang scrap karena semata-mata ingin mendapatkan keuntungan dari pembelian yang dilakukan. Keuntungan tersebut didapatkan dari hasil penjualan kembali yang dilakukan PT. SBS kepada pabrik peleburan besi. Lelang scrap yang diadakan dimenangkan oleh PT. SBS dengan diwakili oleh Syamsudin S.Pd., dengan mengajukan total penawaran sebesar Rp2.102.463.600,00. Momentum kesepakatan jual beli scrap terjadi pada tahap pelaksanaan lelang karena pada tahap ini terjadinya kesepakatan barang yang dijual yaitu 1 paket scrap dengan harga yang telah disepakati. Setelah pelaksanaan lelang diadakan, PT. Pertamina mengeluarkan surat pengumuman pemenang lelang untuk PT. SBS.

\section{2) Tahap penyusunan perjanjian}

Pada tahap penyusunan perjanjian, draft perjanjian jual beli scrap dirancang terlebih dahulu oleh PT. Pertamina. Substansi yang tertuang dalam klausul draft perjanjian jual beli scrap merupakan hasil kesepakatan dari RKS yang dibahas saat agenda penjelasan RKS dan kemudian diejawantahkan menjadi klausul pada perjanjian jual beli scrap tersebut. Setelah draft perjanjian telah selesai dirancang, kemudian draft perjanjian tersebut diberikan terlebih dahulu kepada PT. SBS. Hal ini bertujuan supaya PT. SBS memahami dan memeriksa kembali substansi klausul perjanjian jual beli tersebut (hasil wawancara dengan bapak Ardhian Prasetyo Utomo pada hari Rabu tanggal 10 April 2019 Pukul 13.30 WIB). PT. SBS menyetujui isi perjanjian jual beli scrap nomor 006/ E14000/2016/S0 dikarenakan klausul yang tertuang pada perjanjian jual beli tersebut telah sesuai dengan kebutuhan dan keinginan yaitu kebutuhan yang ingin dicapai PT. SBS yaitu barang scrap yang dibeli sedangkan keinginan yang dicapai PT. SBS semata-mata ingin mencari profit dari hasil penjualan kembali scrap yang dibeli tesebut (hasil wawancara dengan bapak Achmad Rozin pada hari Selasa tanggal 16 April 2019 Pukul 10.30 WIB). Tahap selanjutnya adalah penandatanganan perjanjian jual beli scrap yang diwakili oleh General Manager PT. Pertamina selaku penjual dengan Direktur PT. SBS pada tanggal 8 Juni 2016.

Perjanjian jual beli scrap nomor : 002/E14000/2016-S0 memuat beberapa kesepakatan dan persetujuan mengenai hal-hal sebagai berikut:

a) Pasal 1 memuat mengenai harga ,objek jual beli dan dasar perjanjian

b) Pasal 2 memuat hak dan kewajiban antara PT. Pertamina dan vendor

c) Pasal 3 memuat mengenai perhitungan jumlah berat (tonase)

d) Pasal 4 memuat mengenai cara pembayaran dan mekanisme kelebihan/ kekurangan tonase 
e) Pasal 5 memuat mengenai jangka waktu pelaksanaan

f) Pasal 6 memuat mengenai ketentuan umum sebagaimana yang telah disepakati dan tertuang pada Rencana Kerja dan Syarat-Syarat (RKS)

g) Pasal 7 memuat mengenai pemutusan perjanjian

h) Pasal 8 memuat mengenai ketentuan penggunaan BPJS.

i) Pasal 9 memuat mengenai keadaan kahar

j) Pasal 10 memuat mengenai penyelesaian perselisihan

k) Pasal 11 memuat mengenai pajak dan pungutan

b. Tahap Pelaksanaan Perjanjian

Penulis juga membahas mengenai pelaksanaan perjanjian. Pelaksanaan pekerjaan pengambilan scrap dilakukan PT. SBS berdasarkan Surat Perintah Kerja (SPK) yang dikeluarkan PT. Pertamina terhitung mulai 6 Juni 2016 saat agenda Kick Off Meeting. Agenda Kick Off Meeting dilakukan untuk memberitahukan mengenai teknis dari Pelaksanaan Pekerjaan Perucatan, Pengangkutan, Penyerahan Scrap ke PT. SBS dan penetapan Day One Pelaksanaan Kerja PT. SBS di lokasi Scrap PT. Pertamina. Hasil pembahasan tersebut dicatat pada notula rapat Kick Off Meeting. Pada agenda Kick Off Meeting tersebut, PT. Pertamina mengeluarkan Surat Perintah Kerja untuk PT. SBS. Surat Perintah Kerja seperti yang telah dijelaskan sebelumnya tersebut merupakan surat yang dijadikan dasar dalam melaksanakan pekerjaan pengambilan scrap tersebut (hasil wawancara dengan bapak Ardhian Prasetyo Utomo pada hari Rabu tanggal 10 April 2019 Pukul 13.30 WIB).

Pelaksanaan pekerjaan pengambilan scrap, meliputi penimbangan berat scrap yang diambil. Apabila dalam penimbangan melebihi yang disepakati dalam perjanjian, maka PT. SBS memiliki dua opsi yaitu, membayar kelebihan scrap yang diambil atau merucat scrap tersebut sesuai dengan berat yang telah disepakati. Perucatan merupakan kegiatan menguraikan (memotong) scrap menjadi bagian yang lebih kecil. Perucatan scrap yang dilakukan juga harus memenuhi standar-standar yang telah tertuang pada RKS dikarenakan pekerjaan ini memiliki resiko tinggi. Sehingga dalam pelaksanaan membutuhkan tingkat keselamatan kerja yang tinggi baik dari tenaga kerja, maupun alat yang digunakan. Jangka waktu pelaksanaan pekerjaan selama 60 namun ternyata mengalami kekurangan waktu dikarenakan kurangnya waktu untuk perucatan scrap yang diambil (hasil wawancara dengan bapak Achmad Rozin pada hari Selasa tanggal 16 April 2019 Pukul 10.30 WIB), sehingga PT. SBS mengajukan surat permohonan perpanjangan jangka waktu pelaksanaan pengambilan scrap. Atas permohonan tersebut, maka dibuatlah addendum perjanjian jual beli scrap dengan menambah jangka waktu pelaksanaan menjadi 87 hari. Pelaksanaan pekerjaan pengambilan scrap berjalan dengan lancar walaupun terdapat kendala terkait kurangnya jangka waktu pelaksanaan pekerjaan pengambilan scrap. Pelaksanaan pekerjaan dinyatakan selesai dengan dibuatnya Berita Acara Serah Terima Pelepasan. 


\section{Pembahasan}

Menelaah penerapan asas proporsionalitas dalam perjanjian jual beli scrap antara PT. Perjanjian Jual Beli Scrap PT. Pertamina dengan vendor diukur berdasarkan 4 prinsip sebagaimana dikemukakan oleh Agus Yudha Hernoko sebagai berikut :

a. Prinsip Kesetaraan/Kesamaan Hak yaitu prinsip yang "mengandaikan kesetaraan kedudukan dan hak (equitability)" dengan memberikan pengakuan terhadap hak, peluang dan kesempatan yang sama kepada para pihak untuk menentukan pertukaran yang adil bagi mereka dalam mencapai perjanjian yang bersubtansi asas proporsional;

b. Prinsip Kebebasan merupakan prinsip yang memberikan kebebasan bagi para pihak yang mengadakan perjanjian untuk menentukan substansi yang adil bagi mereka dengan berlandaskan prinsip kesamaan/kesetaraan hak;

c. Prinsip distribusi proporsional merupakan prinsip yang mengacu pada pertukaran yang adil dengan cara menjamin pelaksanaan hak dan juga mendistribusikan kewajiban secara proporsional bagi para pihak;

d. Prinsip win-win solution merupakan prinsip yang digunakan apabila terjadi sengketa dalam perjanjian, maka beban pembuktian, berat ringan kadar kesalahan maupun hal-hal lain terkait harus diukur berdasarkan asas proporsionalitas guna mendapat hasil penyelesaian yang elegan dan win-win solution.

Penulis menelaah asas proporsionalitas pada tahap pembentukan perjanjian dan tahap pelaksanaan jual beli scrap antara PT. Pertamina dengan vendor sebagai berikut : a. Tahap pembentukan perjanjian. Pada tahap ini terdiri atas tahap negosiasi dan penyusunan perjanjian dengan penjabarannya sebagai berikut :

1) Tahap Negosiasi. Tahap negosiasi terdiri atas dua tahap yaitu :

a) Agenda penjelasan Rencana Kerja dan Syarat-Syarat (RKS)

Pada agenda penjelasan RKS, penulis menggunakan 3 prinsip yang dapat mencerminkan bahwa asas proporsionalitas telah terpenuhi saat pembentukan RKS. Pertama, dengan menggunakan prinsip kesetaraan/ kesamaan hak bahwa saat pembentukan RKS, PT. Pertamina telah memberikan kesempatan kepada vendor termasuk PT. SBS untuk menggunakan haknya apabila terdapat hal-hal yang tidak sesuai dengan kebutuhan dan keinginan calon vendor. Kedua, dengan menggunakan prinsip kebebasan, secara tersirat dapat terlihat pada Berita Acara Aanwijzing tertanggal 23 Mei 2016 bahwasanya tidak adanya catatan revisi terkait RKS sehingga dapat dikatakan bahwa calon peserta lelang termasuk PT. SBS menentukan sikap bahwa menyetujui substansi yang terdapat pada RKS. Ketiga, penerapan asas proporsionalitas dalam perjanjian jual beli scrap dengan menggunakan prinsip distribusi proporsional sebagaimana menitiberatkan pada pertukaran hak dan kewajiban para pihak agar berlangsung secara adil. Prinsip distribusi proporsional telah diterapkan karena dua hal yaitu Pertama, PT. Pertamina telah memberikan hak bagi vendor untuk memberikan usulan apabila terdapat substansi draft RKS yang tidak sesuai dengan kebutuhan dan keinginan vendor, namun pada pelaksanaan agenda Aanwijzing, tidak terdapat catatan perubahan terkait 
draft RKS pada Berita Acara Aanwijzing. Kedua, Vendor juga menyetujui tanpa adanya usulan revisi terkait substansi RKS sehingga atas kesepatan kedua belah pihak, RKS tersebut dibentuk.

b) Tahap pelaksanaan lelang

Pada pelaksanaan lelang, asas proporsionalitas dalam perjanjian jual beli scrap antara PT. Pertamina dengan vendor telah diterapkan dengan mengacu pada 3 prinsip yaitu Pertama, dengan penggunaan prinsip kesetaraan hak. Vendor yang notabenya juga termasuk PT. SBS mendapatkan hak untuk melakukan penawaran terhadap barang scrap yang dilelang sedangkan PT. Pertamina mendapat hak untuk mendapatkan harga penawaran tertinggi dari hasil lelang. Kedua, prinsip kebebasan telah diterapkan dengan adanya pengakuan hak melakukan penawaran terhadap barang scrap tersebut, vendor yang terdiri juga dari PT. SBS dapat menentukan harga penawarannya sesuai dengan penawaran yang diajukan sehingga PT. SBS yang memenangkan lelang scrap tersebut. Ketiga, yaitu dengan prinsip distribusi proporsional. Prinsip ini menjamin pelaksanaan hak dari antara PT. Pertamina dengan vendor. Pelaksanaan hak yang dimiliki PT. Pertamina dengan vendor telah terjamin dengan melihat bahwasanya PT. Pertamina mendapatkan harga penawaran tertinggi sebesar Rp2.102.463.600,00 (dua milyar seratus dua juta empat ratus enam puluh tiga ribu enam ratus rupiah) yang diajukan vendor yaitu PT. SBS. Pelaksanaan hak yang dimiliki vendor dapat dilihat dari PT. SBS ditetapkan pemenang lelang. Berdasarkan hak yang dimiliki vendor untuk menentukan harga penawarannya sendiri sehingga vendorvendor yang mengikuti lelang tersebut saling melakukan penawaran sesuai dengan keinginannya dan menghasilkan PT. SBS sebagai pemenang lelang.

2) Tahap Penyusunan Perjanjian

Pada tahap penyusunan terdapat 4 prinsip yang dapat mencermikan bahwa asas proporsionalitas telah diterapkan pada perjanjian jual beli scrap nomor 002/E14000/2016-S0 yaitu Pertama, prinsip kesetaraan hak. Prinsip ini dapat dibuktikan bahwasanya PT. Pertamina memberikan kesempatan kepada PT. SBS untuk melihat, membaca, dan memahami kembali substansi dari draft perjanjian jual beli scrap tersebut. Hak lainnya yaitu dalam hal menentukan sikap untuk menyepakati atau tidak draft perjanjian jual beli scrap yang diajukan oleh PT. Pertamina. Kedua yaitu prinsip kebebasan. Berlandaskan hak yang diberikan kepada PT. SBS, prinsip ini juga digunakan pada perjanjian jual beli scrap nomor : 002/E14000/2016-S0 saat menentukan sikap untuk menyepakati perjanjian jual beli scrap berlandaskan pemberian kesempatan/hak dari PT. Pertamina dengan hasil bahwasanya PT. SBS menyepakti perjanjian tersebut. Ketiga yaitu prinsip distribusi proposional. Penggunaan prinsip distribusi proporsional dibuktikan dengan terlaksananya hak untuk melihat, membaca, dan memeriksa kembali substansi dari draft perjanjian jual beli scrap dan hak untuk menyepakati atau tidak perjanjian jual beli scrap tersebut sebagaimana hak tersebut merupakan hak yang diberikan oleh PT. Pertamina. Keempat yaitu prinsip win-win solution. 
Prinsip ini digunakan dengan melihat klausul yang terdapat dalam perjanjian sebagaimana yang tertuang pada Pasal 10 yaitu apabila terjadi perselisihan akan diselesaikan secara musyawarah. Hal tersebut merupakan usaha untuk mengantisipasi permasalahan yang terjadi dengan tidak merugikan kedua belah pihak.

\section{b. Tahap Pelaksanaan Perjanjian}

Pada tahap ini, prinsip distribusi proporsional yang digunakan pertama dalam menelaah perjanjian ini. Pada perjanjian jual beli scrap ini,PT. SBS memiliki kewajiban yaitu Pertama, melakukan pembayaran jaminan kebersihan sesuai dengan ketentuan yang berlaku sebagaimana hal ini merupakan hak PT. Pertamina untuk sementara waktu selama proses pelaksanaan pekerjaan pengambilan scrap berlangsung. Kedua, PT. SBS melaksanakan pengambilan scrap sesuai RKS dan aturan lain yang berlaku. PT. SBS juga memiliki hak katas kepemilikan scrap setelah melaksanakan kewajiban yang dimilikinya. Pada perjanjian jual beli antara PT. Pertamina dan PT. SBS, PT. Pertamina memiliki hak yaitu menerima hasil pembayaran atas penjualan scrap dan menerima uang jaminan kebersihan sesuai dengan ketentuan yang berlaku. Selain hak yang didapat, terdapat kewajiban yang harus terdistribusi sebagaimana yang tertuang pada Pasal 1474 KUH Perdata yaitu, kewajiban untuk memberikan hak kepemilikan scrap atas pekerjaan pengambilan scrap yang dilakukan PT. SBS atas transaksi jual beli yang dilakukan oleh kedua belah pihak. Prinsip Kesetaraan merupakan prinsip kedua yang digunakan. Selama pelaksanaan pekerjaan pengambilan scrap, terdapat hambatan yang terjadi, seperti contoh kurang waktu pelaksanaan pekerjaan yang dialami PT. SBS (hasil wawancara bapak Achmad Rozin). PT. SBS kemudian mengajukan surat permohonan penambahan jangka waktu pelaksanaan pekerjaan pengambilan scrap. Berdasar pada surat permohonan penambahan jangka waktu pelaksanaan pekerjaan tersebut, PT. Pertamina memberikan kesempatan terhadap PT. SBS. Hal ini dilakukan supaya PT. SBS tetap dapat melanjutkan pekerjaan dan mendapatkan haknya yaitu barang scrap yang telah dibeli tersebut. Ketiga yaitu, prinsip kebebasan. Kebebasan yang dimaksud merupakan kebebasan PT. SBS menentukan durasi penambahan jangka waktu pengambilan scrap dengan dikeluarkannya surat nomor : 10/SBS/VII/2016 tertanggal 29 Juli 2016 perihal pengajuan permohonan perpanjangan jangka waktu pelaksanaan pengambilan scrap. Berdasar pada surat yang diajukan tersebut, maka PT. Pertamina dan PT. SBS sepakat untuk mengikatkan diri pada Addendum Perjanjian Jual Beli Scrap nomor: 006/E14000/2016-S0. Pada addendum perjanjian jual beli tersebut, klausul yang mengatur jangka waktu pelaksanaan pengambilan scrap dilaksanakan menjadi 87 (delapan puluh tujuh) hari kalender yang semula pada perjanjian jual beli scrap nomor : 002/E14000/2016/S0 untuk klausul jangka waktu pelaksanaan pengambilan scrap yaitu selama 60 hari kalender. Prinsip terakhir yang digunakan yaitu prinsip penyelesaian win-win solution. Prinsip ini tidak dapat digunakan pada perjanjian jual beli scrap nomor : 002/E14000/2016/S0 karena saat pelaksanaan perjanjian tidak terjadi sengketa. Adapun permasalahan yang terjadi yaitu mengenai kurangnya jangka waktu pelaksanaan pekerjaan yang telah tertuang dalam perjanjian. 


\section{Simpulan}

Asas Proporsionalitas dalam perjanjian jual beli scrap antara PT. Pertamina dengan vendor telah terpenuhi pada tahap pembentukan dengan menggunakan 4 prinsip yaitu prinsip kesetaraan hak, prinsip kebebasan, prinsip distribusi proporsional, dan prinsip win-win solution sedangkan pelaksanaan perjanjian menggunakan 3 prinsip yaitu prinsip kebebasan, prinsip kesetaraan hak, dan prinsip distribusi proporsional. Pelaksanaan perjanjian berjalan lancar walaupun dalam pelaksanaan perjanjian terdapat kendala terkait kurangnya waktu pelaksanaan pekerjaan pengambilan scrap.

\section{E. Saran}

Berdasarkan simpulan yang di dapat, maka penulis memberikan saran kepada PT. Pertamina dan vendor agar memperhitungkan secara matang terkait jangka waktu pelaksanaan sehingga dapat sesuai dengan yang telah tertuang dalam perjanjian jual beli scrap yang diadakan PT. Pertamina dengan vendor. Penulis juga memberikan saran kepada pemerintah cq Kementrian Badan Usaha Milik Negara agar melakukan pengawasan yang komprehensif terhadap BUMN yang melakukan pelepasan aset scrap. Hal ini bertujuan untuk mencegah praktik KKN yang dilakukan oleh oknum tertentu untuk mendapatkan keuntungan bagi diri sendiri maupun kelompok tertentu.

\section{F. Daftar Pustaka}

\section{Buku}

Agus YudhaHernoko. 2010. Hukum Perjanjian Asas Proporsionalitas Dalam Kontrak Komersial. Jakarta : PT Kencana.

H.B. Soetopo. 2006. Metodologi Penelitian Kualitatif. Surakarta: UNS Press.

Soerjono Soekanto, Sri Mamudji. 2014. Penelitian Hukum Normatif Suatu Tinjauan Singkat. Jakarta : Raja Grafindo Persada.

\section{Jurnal Nasional dan Jurnal Internasional}

Agus Yudha Hernoko. 2016. “Asas Proporsionalitas sebagai Landasan Pertukaran Hak dan Kewajiban para Pihak dalam Kontrak Komersial”. Jurnal Hukum dan Peradilan. Volume 5. Nomor 3. Halaman 447-466.

David P. Weber. 2013. "Restricting the Freedom of Contract : A Fundamental Prohibition". Yale Human Rights and Development Law Journal. Volume 16, Issue 1. Connecticut : Yale Law School.

Rewi Lukiatsinto dan Noeroel Widajati. "Penerapan CSMS (Contractor Safety Management System) Sebagai Upaya Pencegahan Kecelakaan Kerja". The Indonesian Journal of Occupational Safety and Health. Volume 3, Nomor 2 Halaman 192-200. Surabaya : Universitas Airlangga. 
Rudhi Prasetya. 1997. Analisis Hukum Ekonomi terhadap Kontrak dalam Menyongsong Era Globalisasi. Jurnal Hukum Bisnis. Volume 2, Halaman 21.

\section{Surat}

Pertamina dan PT. SBS, Perjanjian Jual Beli Barang Bekas/Scrap/Rongsokan antara PT. Pertamina RU IV Cilacap dengan PT. Sokojati Bumi Serasi No. 002/E14000/2016-S0

\section{Wawancara}

Ardhian Prasetyo Utomo,S.H., pada hari Rabu tanggal 10 April 2019 Pukul 13.30 WIB Achmad Rozin,S.E., pada hari Selasa tanggal 16 April 2019 Pukul 10.30 WIB 